\title{
RENDSZERTÉRKÉPEZÉS ALKALMAZÁSA A HAZAI DEMENCIASTRATÉGIA MEGALAPOZÁSÁHOZ
}

A társadalom elöregedése fenntarthatósági kihívások elé állítja a nemzeteket. A várható élettartam növekedését a betegségben eltöltött évek számának emelkedése kíséri, mely azonban az egészségipari és ellátási fejlesztéseknek köszönhetően nem jár életminőség romlással. Speciális esetet jelent a demencia, melynek kialakulására az életkor növekedésével egyre nagyobb esély van. A demenciával élők száma tehát növekedni fog, és mivel ez tartós és fokozatosan növekvő mértékű ápolási szükséglethez vezet, így kiemelt tényezője az időskori kiszolgáltatottságnak és az életminőség romlásának. A társadalmi fenntarthatóság ilyen jelentőségű kihívása esetén stratégiai tervezés, felkészülés, cselekvési program kidolgozása szükséges. Számos európai ország rendelkezik már a probléma megoldását célzó demenciastratégiával.

Jelen cikk egy kísérleti jelleggel alkalmazott kvalitatív módszert, a részvételi rendszertérképezést (participatory systems mapping) mutatja be, mint lehetséges eszközt egy demenciastratégia megalkotásában. A rendszertérképezés és a részvételmódszertanok együttes alkalmazásának előnyei eddigi tapasztalatok alapján jól érvényesülnek szakpolitikai területeken, hosszabb távú tervek, rövidebb távú beavatkozási programok kidolgozásánál.

A demenciával élők életminőségének javítását középpontba állító, komplex oksági diagram készítésének vizuális eszközét alkalmazó, egymástól eltérő tudásbázisú résztvevők bevonásával szervezett együttgondolkodás tapasztalatai előremutatóak és a módszer további alkalmazására ösztönzőek. A kísérlet során sikerült prioritásként kezelhető kiemelt témákat, problémákat azonosítani, mindemellett a résztvevők megtapasztalták a részvétellel járó pozitív hatásokat, valamint érvényesült az ábrázolás kommunikációtámogató célja.

Kulcsszavak: rendszertérképezés, részvétel, társadalom elöregedése, demencia, stratégia

$\mathrm{H}$ azánk különösen érintett a társadalom elöregedésének világszinten tapasztalható, szerteágazó hatásokkal járó folyamatában. Magyarországra vonatkozó előrejelzések szerint a populáció életkor szerinti összetétele 2060-ra drámaian meg fog változni. Az Eurostat adatai alapján (Eurostat, 2014) Magyarországon 2013-hoz képest 2060-ra a 65 év felettiek aránya 12\%-kal, a 80 év felettiek aránya közel 16\%-kal nő, ugyanakkor az aktív korúak (15-64 év közöttiek) aránya 12\%-kal csökken, míg a gyermekkorúak aránya lényegében változatlan marad. Plasztikusabban ugyanez kifejezve: míg 2013-ban egyetlen 80 év feletti mögött 16 aktív korú sorakozott fel, addig 2060-ban már nem egészen 5 fó áll majd helyt. Ez a demográfiai folyamat, melyet a szakirodalom „elöregedés” (ageing/ aging) névvel illet, fenntarthatósági kihívások elé állítja a nemzeteket, mivel új megoldások szükségesek többek között a nyugdíj-, az egészségügyi, valamint a szociális ellátás rendszerében. A kihívások egyik - ma hazánkban még fel nem ismert jelentőségü - előidézője a demencia terjedése.

A várható élettartam növekedését a logika és a tapasztalat alapján a betegségben eltöltött évek számának emelkedése kíséri, mindamellett, hogy a betegségek kialakulása többnyire multifaktoriális. Az egészségipari és ellátási fejlesztéseknek köszönhetően a világ fejlett országaiban az idősebb kort megérőknek sem kell számolniuk a funkcionális korlátozottság növekedésével, az életminőség romlásával annak ellenére, hogy a krónikus - például szív- és érrendszeri, légúti vagy anyagcsere - betegségek, valamint a rosszindulatú daganatos megbetegedések előfordulása is nőni fog (Christensen et al., 2009). Speciális esetet képez a demencia, mivel elsődlegesen éppen bizonyos képességek romlása, a funkcionális korlátozottság képezik a tünetegyüttes összetevőit, tehát azok nem következményként, hanem elsődleges betegségjelzőként lépnek fel.

A demencia a kognitív, gondolkodási funkciók hanyatlásával járó folyamat, melynek legszembeötlöbb jele a memóriafunkció elvesztése, az életkorral összefüggő kórkép. Ma már elavult fogalmak, de korábban ezt a kóros folyamatot ,időskori elbutulás” vagy „,szenilitás” megnevezésekkel illették, mely nomenklatúra azt is kifejezte, hogy az állapotra az öregedés természetes részeként tekintettek. Ez a téves szemlélet is szerepet játszhatott abban, hogy miért nem irányult eddig kellő figyelem a probléma mértékére.

A demencia többféle kórfolyamat eredményeként is kialakulhat, döntő részben azonban nem gyógyítható, a mai terápiás lehetőségektől legfeljebb a tünetek mérséklése és a folyamat elörehaladásának lassítása remélhető. A tünetegyüttes elörehaladásával a betegek kiszolgáltatottsága fokozatosan nö, végül az önálló életvitel folytatására is képtelenné válnak, és akár 10 évig is ápolásra szorulnak (Aguero-Torres et al., 1998).

Nemzetközi becslések (EUROCODE Project: Dementia in Europe Yearbook 2006) a világszintü prevalencia adatokat alapul véve Magyarországon legalább 110-130 ezer demenciával élö beteget feltételeznek, akiknek csak a töredékét azonosítja, gondozza és kezeli a hazai egészségügyi és szociális ellátás rendszere. Más szakértői vélemény akár 2-300 ezer ember érintettségét is elképzelhetőnek tartja, és a 85 év feletti korosztályban 30\%-ra becsüli a demenciával 
élők arányát (Kovács, 2016). Tekintve a társadalom elöregedésének tendenciáját, a demenciával élők számának jelentős növekedésével kell számolnunk, és időben fel kell készülni ennek a tehernek a kezelésére. A társadalmi fenntarthatóság ilyen jelentőségü kihívása esetén joggal vetődik fel a kérdés: hogyan érdemes stratégiailag tervezni, felkészülni a valószínüsíthetően várható helyzetre.

Jelen cikk bemutatja azt a kísérleti jelleggel alkalmazott kvalitatív módszert, a részvételi rendszertérképezést (participatory systems mapping), ami egyik eszköze lehet a demenciastratégia alkotási folyamatának. A rendszertérképezés módszere alkalmas sokféle érintett szereplö bevonására és együttgondolkodásának strukturálására. A részvételiség biztosítja a sokféle szempont, tudás és tapasztalat egy színtéren történő megjelenését. A közösen létrehozott oksági struktúra térképszerűen megjelenítve akár azonnali visszajelzést ad a résztvevőknek közös alkotásuk fö elemeiröl, az elemek közötti kapcsolatokról, s az intervenció hatásosnak tetsző pontjairól.

\section{Háttér - a demencia társadalmi jelentősége}

A magyar populáció elörejelzett öregedési tendenciája miatt hazánkban a demencia, a gondolkodási funkció elörehaladott zavara hamarosan komoly össztársadalmi problémát fog jelenteni a tünetcsoporttal érintettek (betegek) tömege miatt (EUROCODE Project: Dementia in Europe Yearbook 2006). A probléma komplexitása részben a betegség jellemzőiböl következik, így célszerü ennek rövid áttekintése, melyben a számos, helyenként egymásnak ellentmondó orvosszakmai forrás mellett már konszenzuson alapuló szakértői véleményeket összegző tanulmányra is támaszkodhatunk (Annear, 2015). A demencia, Alzheimer-demencia, Alzheimer-kór kifejezések hallatán legtöbbeknek a memóriazavar, emlékezöképesség elvesztése, mint társuló fogalmak jutnak eszébe, ugyanakkor a gondolkodási funkció romlása nem csupán a memória, az emlékezőképesség területén okoz problémát, hanem egy sor egyéb megnyilvánulása van. Így a tünetek közé tartozhat a figyelem fenntartásának, vagy a döntésképességnek az elvesztése, a tervezés, a szervezés, a problémamegoldás képességének zavara, az ítélőképesség bizonytalanná válása, vagy akár a kifejezőképesség, a beszéd nehezítettsége. Mindezeket sorra véve azonnal több olyan mindennapi élethelyzetet tudunk felidézni, melyben egy demenciával élő segítségre, támogatásra szorul. Meg kell említeni, hogy a demencia nem kizárólag az időseket érintő kórkép, hanem aktív korú, akár 50 éves embereknél is kialakulhat igen súlyos formája. Elsődleges forma esetén a minél koraibb felismerés, a gyakran más pszichiátriai betegség - leginkább depresszió - tüneteit mutató beteg szakemberhez irányítása lenne a legfontosabb lépés, míg másodlagosan, a közvélemény által is ismerten népbetegség szintjén nyilvántartott agyi érkatasztrófa (másnéven sztrók) bekövetkezése után a megelözésre kellene nagyobb figyelmet fordítani (Kling, 2013).

Amikor egy probléma kezelését célzó cselekvési terv, stratégia felvázolására készülünk, fontos azonosítani az elsődlegesen érintetteket, hisz a leghatékonyabb beavat- kozást ezt a kört érintően tehetjük meg. Emellett, ha a részvételre, mint tudásintegrációs módszertani lehetőségre tekintünk, akkor az elsődlegesen érintettek bevonása is mérlegelendő. Hangsúlyozandó különlegessége a demenciának, hogy elsődleges érintettnek nemcsak maga a demenciával élö személy tekintendő, hanem az őt gondozó családtag vagy más önkéntes segítő is, hiszen a tünetegyüttes - nem véletlenül részletezett - összetettségéből adódóan a diagnózis felállításának pillanatában azonnal egy támogató, majd később aktív, folyamatos ápolást biztosító személyt kell a beteg állandó társaként számba venni. E társ a legtöbb esetben egy családtag, aki kényszerüség okán, vagy ritkább, de szerencsésebb esetben önként választva került ebbe a szerepkörbe. Ez az informális ápolói, gondozói szerep több megközelítésből is a kutatói érdeklődés fókuszában áll (Etters et al., 2008; Fonareva et al., 2014; Krol et al., 2015): az ápolást végző személy pszichológiai jóllététől, a nála fellépő testi betegségeken át a tevékenységnek a közgazdasági vonatkozásáig, több téma is egy-egy kutatás középpontjába állítható.

Érintett ugyanakkor a problémában a teljes szociális és egészségügyi ellátó hálózat, valamint a társadalom egésze, mivel részt kell vállalnia a közvetlenül érintettek összetett és jelentős terheinek mérséklésében, melyre elsődlegesen anyagi vonatkozásban, nemzetgazdasági megközelítésben adódik lehetősége a költségvetésből fedezett szociális és egészségügyi kiadások forrásainak adók és járulékok formájában történő megfizetése révén. Az Egészségügyi Világszervezettel (World Health Organization, WHO) együttműködésben dolgozó, világszinten több, mint 80 tagot tömörítő Alzheimer's Disease International nevü szervezet 2009 óta jelenteti meg World Alzheimer Report címü kiadványát, melynek először a 2010-ben kiadott száma foglalkozott kiemelten a gazdasági hatásokkal, majd 2015-ben tértek vissza e témára, és az eltelt öt évben a társadalmi költségek növekedését 35\%-ra tették. A három fő költségtényező közti megoszlás viszonylag állandónak mutatkozik: a direkt egészségügyi költségek tesznek ki 20\%-ot, míg a szociális ellátás költségei és az informális ellátás költségei egyenlően körülbelül 40-40\%-ot képviselnek. A költségek összetettsége is utal a demenciához kapcsolódó problémakör komplexitására.

\section{Európai demenciastratégiák - miértek és hogyanok}

Az Európa Tanács 2002-ben, az idősödő társadalom jelentette szociálpolitikai kihívásokkal kapcsolatban megfogalmazott ajánlása a demenciát is megemlíti azok között a krónikus betegségek, állapotok között, melyek az időskorúak fokozott kiszolgáltatottságához és életminőségük romlásához vezet. A WHO 2008-ban emelte a demenciát a prioritást élvező kórképek közé, majd 2013-ban a gyógyszerfejlesztés világszintü koordinációját célzó kiadványában (WHO, 2013 Priority Medicines for Europe and the World - A Public Health Approach to Innovation) került azon 24 kórállapot, betegség listájára, melyek olyan jelentős társadalmi terhet okoznak, hogy kiemelkedő fontosságú a terápiás lehetőségek terén fejlődés elérése. 
Tekintettel a demencia által képviselt probléma összetettségére és mértékére, kezelésére nemzeti stratégia kell. Ezt elsőként Franciaország ismerte fel, ahol 2001-ben fogadták el az első cselekvési tervet, és ma már a 4. program fut. Mint minden, a szociális és egészségügyi ellátó rendszerre jelentős mértékben építő programnál, egyediséget követel, hogy a cselekvési tervet a fennálló, vagy reálisan kialakítható ellátási rendszerhez kell igazítani - legalább az első lépéseknél. Emellett a nemzeti sajátság másik forrását a szociokulturális hagyományok adják, melyek nem hagyhatók figyelmen kívül különösen egy ilyen területen, ahol a családi és a legtágabb értelmü társadalmi kapcsolatok szintjén is hatást gyakorló beavatkozásra van szükség.

Mára 21 európai tagállam rendelkezik demenciastratégiával. 2016-ban négy ország - Cseh Köztársaság, Görögország, Szlovénia, Spanyolország - is eljutott a stratégiája kormányzati kihirdetéséig a több éves előkészítő folyamat eredményeként. Az egészségügyi és szociális területet egyaránt érintő cselekvési tervek a legtöbb esetben egy önszerveződő szakértői csoport kezdeményezésére születnek meg, és a kormányzati szervek különböző mértékü bevonása, beavatkozása után a kormányok által meghirdetett programként lépnek a megvalósulás útjára. A szakértőket rendszerint az adott ország Alzheimer-kórral és egyéb demenciákkal élöket képviselö, demenciával élőket gondozó személyeket és intézményeket tömörítő szervezete vagy szervezetei delegálják, illetve hívják fel az együttes munkára. Az első lépés rendszerint egy fórum kialakítása, ahol a szakértők a tudásukat megoszthatják. Ez valahol egy tanulmánykötet, összegző riport megalkotása, máshol egy konferencia, szimpózium szervezése keretében történt. Ezt követően kerül sor általában az elsődlegesen kitűzendő célok, a végrehajtandó feladatok megfogalmazására. A szakértők által elkészített stratégiai dokumentum munkaverzióját rendszerint nyilvánosságra hozzák, vitára bocsátják, és az arra születő reflexiók alapján készül el az a végleges verzió, melyet államirányítási szinten hirdetnek ki, fogadnak el. A cselekvési tervek rendszerint 3-5 évre szabnak feladatokat, így a stratégiaalkotásban élen járók már többedik programjukat hirdetik ki, melyek az előzőekben megfogalmazott célok megvalósulásának értékelésén alapulnak. Fontos tehát, hogy a meghatározott prioritások mérhetőek, értékelhetőek legyenek. (1. ábra)

1. ábra

\section{A demenciastratégia kialakításának folyamata a nemzetközi gyakorlatban}

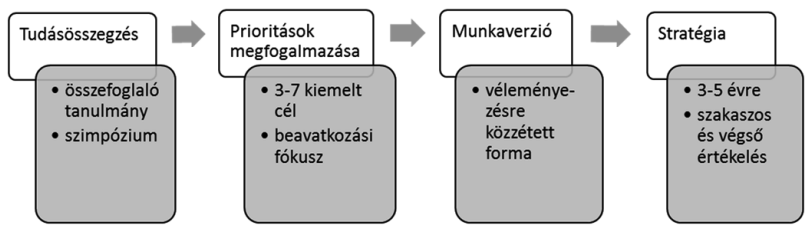

Hazánk nem rendelkezik stratégiával, még vitára bocsátott munkaverzióval sem, így lemaradásunk években mérhető. A hazai szemlélet formálásának szükségességét mutatja, hogy a demencia egyre nagyobb tömegeket érintô és az egészségügyi és szociális ellátó rendszerre egyre nagyobb terhet rovó tényezőként sem az egészségügyi (Egészséges Magyarország 2014-2020), sem a szociális terület általános stratégiájában (Nemzeti Szociálpolitikai Koncepció 2011-2020; 2011) nem kerül említésre, szemben ennél jóval kisebb társadalmi és költségvetési jelentöségü kórképekkel.

\section{Módszertan - kvalitatív megközelítés alkalmazása a tudásösszegzéshez}

A rendszertérképezés és a részvétel mint módszertanok, összekapcsolt alkalmazása viszonylag friss megközelítés (Király et al., 2015). Jellemzően szakpolitikai területeken tud érvényesülni a metódusok együttes alkalmazásában rejlő számos előny, így stratégiafejlesztésnél, hosszabb távú tervek megfogalmazásánál, vagy rövidebb távú beavatkozási programok kidolgozásánál érdemes a kombinált módszerhez fordulni. A rendszertérképezés a rendszerdinamikai megközelítés alapján a negatív és pozitív visszacsatolások, hurkok ábrázolása útján feltárja azokat a lehetséges beavatkozási pontokat, melyek bármely probléma megoldásához szükséges döntések célpontjai lehetnek (Vennix, 1996). Ahogy az a módszer megalkotójának, J. W. Forresternek az életmüvében is követhető, mérnöki technológiafejlesztés vezetett egy vezetéselméleti vívmány megalkotásához az 50 -es évek végén, melyet az elmúlt évtizedek alatt egyre szélesebb körben használtak fel (Lane, 2007). Miután nyilvánvalóvá vált, hogy a mérnöki után a menedzsmenttudomány területen is müködőképes a rendszerdinamikai modellezés, a vállalati után a komplex társadalmi rendszerek összefüggéseinek tisztázására is alkalmasnak tűnt. Mint ilyet, először egy város működési dinamikájának feltérképezése során használta maga Forrester, majd 1970-ben felkérték a világ globális fejlődésének rendszerdinamikai elemzésére, melynek során a fejlődés fenntarthatóságának tényezőit tárta fel a módszerrel. E munka folytatásaként került sor a módszer alkalmazására a természeti környezettel kapcsolatos rendszerek kutatásában. Később számos egyéb tudományterületen alkalmazták ezt az elemzési módszert. Az egészségtudományok területén is található csekély számú példa. Alkalmasnak találták közegészségügyi problémák - melynek a demencia is tekinthető - feltárására, mivel transzdiszciplináris szemléletre van szükség a biológiai, szervezeti és politikai elvek egyidejü érvényesítése érdekében és a módszer megfelelő eszköz ezen elvárás biztosításához (Leischow, 2006).

A részvétel biztosításának szükségességét a társadalompolitikai döntésekben már az évezred elején elvárásként fogalmazták meg annak pontos tisztázatlansága mellett, hogy mit is kell részvétel alatt érteni (Bishop, 2002). A kormányzat és a döntéshozók gyakran egyfajta szürőn keresztül észlelik csak a mindennapi történéseket, a társadalmi rendszerek müködését, így azok feltérképezése nem képzelhető el a valódi érintettek bevonása nélkül. A bevonás különböző szintü lehet: az információforrásként való felhasználástól a döntéshozatalba való bevonásig terjedhet. 
Ezen „ajánlások” jelentették a cikkben bemutatott, kísérleti jelleggel végzett, stratégiát megalapozó együttgondolkodás kiindulópontját. A kísérlet több szempontból egyedi: egészség- és szociálpolitikai területen hazánkban a stratégiaalkotás nem rendelkezik nagy hagyományokkal, és még kevésbé jellemző a professzionális vagy laikus célközönség bevonása egy problémafelmérésbe, vagy cselekvési terv megalkotásába. E szakterületeken még nemzetközi viszonylatban is nehéz példákat találni az érintettek bevonásával zajló, rendszertérképezésen alapuló programalkotásra.

Megismerve a kombinált módszertan hazai gyakorlatban is igazolt elönyeit (Király, 2014), született meg a döntés a kutatás kivitelezésének módjáról. Elöször is a módszer feltáró jellegủ, és az oksági összefüggések ábrázolása különösen támogatja a probléma mélyebb megértését. Másrészt az együttgondolkodás folyamata során úgynevezett változókra és az azok közti összefüggésekre koncentrál a diskurzus, mely semleges kommunikációt tesz lehetővé, hiszen nem ideológiákat, komplex véleményeket kell megfogalmazni, hanem konkrét tényezőkröl és azok közti kapcsolatokról szól az eszmecsere. Mindez azt is elősegíti, hogy egymástól akár jelentősen eltérő tudásbázisú, más fókuszú, vagy szintű tudással rendelkező résztvevők képesek legyenek együtt dolgozni. Harmadrészt, mint általában a vizuális technikák, a gondolkodás, a tudásöszszegzés eredményének képi megjelenítése megkönnyíti a dokumentációt, akár a folyamat szakaszait akarjuk követni, akár a végeredményt kívánjuk rögzíteni, elemezni. Az ábrázolást és elemzést szabadon elérhető szoftverek is segítik. Szintén fontos, és a módszer kiválasztásának szempontjából talán elsődleges volt a módszer azon jellemzője, hogy könnyen tanulható és tanítható, azaz átadható a technika.

Mind a négy kiemelt alapvető módszertani előny hozzájárult ahhoz, hogy a demenciastratégia készítésének megalapozását célzó tudásszintézishez részvételi rendszerdinamikai eszközhöz nyúljunk kísérletképpen. A módszer további előnyeinek számbavételénél érdemes a részvétel és rendszertérképezés elemeket egy időre szétválasztani. A részvétel biztosításának előnyei, különösképpen hazánkban, még mindig hangsúlyozásra szorulnak (Király, 2014). Talán a legkönnyebben elfogadott érv mellette, hogy több embernek több a tudása, minden egyes szereplö potenciálisan valamit hozzáad a kollektív tudáshoz. Fontos azonban kicsit e mögé is nézni. Maga a részvétel biztosítása egy pszichológiai értelemben vett szükségletkielégítő módszer, és ezáltal a résztvevő jóllétének javításához is hozzájárul, valamint őt motiváltabbá teszi. Ha a döntéshozó számára biztosított a részvétel, akkor tőle megalapozottabb, jobb döntés remélhető a részvétele útján hozzá eljutó több információ révén. A részvétel különböző pozícióban lévő szereplők számára találkozási, közvetlen kapcsolati lehetőséget is biztosít, mely már meglévő vagy potenciálisan kialakuló konfliktusok kezelésére, ideális esetben megelőzésére is lehetőséget ad. A társadalom egészét tekintve a „demokratikus/demokrácia deficit” csökkentésének bármely módja, így ez az eszköz is haszonnal kecsegtet. A hétköznapi, egy adott problémával minden nap szembesülő ember és döntései által közvetetten az ő életét mindennapi szinten befolyásoló döntéshozó eltávolodása mára jelentős probléma. A részvétel biztosítása - ha nem is a társadalmi spektrum két legszélső pontjának találkozását, de legalább - köztes szereplők közvetlen kommunikációját tudja biztosítani. Kiemelt jelentőségű a résztvevők személyének helyes megválasztása, ugyanakkor a részvétel módja, formája is, hogy a résztvevők kellő szabadságot élvezzenek a folyamat során. A téves elvárások elkerülése érdekében a részvétel kimenetét, a folyamat végső célját is célszerü elöre tisztázni a szereplőkkel, hogy se későbbi csalódás, se menet közbeni visszafogott motiváltság ne alakuljon ki.

A rendszertérképezés egyik kritikus eleme az úgynevezett belső nézőpont alkalmazása (Richardson, 2011). Eszerint a vizsgált rendszer működését, viselkedését befolyásoló tényezők közül azok képezik a modell szerves részét, melyek szerepet játszanak annak dinamikájában, visszacsatolás, egymásra tett hatásokból képzett zárt hurkok képzése révén. Ebből következően alkalmazása az interdiszciplináris együttmüködés felé tett lépésnek is tekinthető kutatási aspektusból, mivel ábrázolja az eltérő szakterületekhez tartozó tényezők egymásra hatását a vizsgált rendszeren belül, és ha mindezt a részvétellel kombináljuk, akkor elérhetjük a transzdiszciplinaritás szintjét, azaz amikor nem csupán arra van lehetőség, hogy a különböző szakterületek eltérő szemlélete felszínre kerüljön, hanem hogy az eltérő nézőpontok és tudástípusok mintegy kölcsönhatásba lépve, egymást formálják is. Ez tekinthető egyfajta közös tanulási folyamatnak is, hiszen mindenkinek gazdagodik a meglévő ismeretanyaga és formálódik a szemlélete. Mivel a tárgyalandó problémáról senkinek nincs meg az átfogó tudása, így elengedhetetlen az egyéni szereplők tudás- és szemléletmozaikjainak összeillesztése. Erre kínál megfelelő lehetőséget a részvételi rendszertérképezés, melynek célja, hogy a tudás kollektivizálása után, a felvázolt összefüggésrendszer alapján beavatkozási pontokat azonosítsanak a résztvevők, és akár különböző távú cselekvési programokat építsenek fel.

A módszer korlátait szintén meg kell említeni, ugyanis - saját tapasztalataink alapján is - a résztvevők jelentősen befolyásolni tudják a kimenetet. Bár a kommunikációt az eltérő tudásszintủ résztvevők között valóban jelentősen megkönnyíti az ábrázolási technika, és a változókra épített gondolatfüzés valóban leegyszerüsíti a komplexitást, de a rendszertérképezés jelentőségének felismerése egyfajta elvontabb gondolkodást, magasabb szellemi teljesítményt igényel, és ezáltal a résztvevők egy részének szellemi fölénye akár eltolódást eredményezhet még elemszintű megközelítés esetén is. Hasonló okra vezethető vissza, hogy a koncentrált gondolkodás nem azonos mértékủ kifáradást fog eredményezni az inkább kutató, elméleti szakemberek és a gyakorlati területen dolgozó szakemberek között. A moderátornak így fontos feladat jut a munkafolyamat megfelelő felépítésében, és az eszmecsere során a kiegyenlített megnyilvánulási lehetőségek biztosításában. 


\section{A tudásösszegző céllal folytatott részvételi rendszerdinamikai modellezés - a szervezéstől a végrehajtásig}

A fenti elméleti alapvetések mentén kezdődött az eszmecsere szervezése, melynek központi eleme volt egy olyan szervezet, amelynek szerepe a hazai demenciaügy képviseletében azóta hivatalosan is igazolást nyert. A Szociális Klaszter Egyesület, mely ápolóotthonokat, idősápolást végző intézményeket, illetve a területhez bármely szempontból kötődő egyéni tagokat tömörít, 2016 októberében nyert felvételt az Alzheimer Europe ernyőszervezetbe. A szervezet 2016. novemberi jelentése alapján 34 ország 39 szervezetét, mint teljes jogú tagot, tömöríti, és további 4 ország 4 szervezete - köztük Magyarországról elsőként a Szociális Klaszter - mint leendő tag szerepel a partnerek között.

A Szociális Klaszter az idősellátásban és ezzel együtt a demenciával élök ellátásában érintett intézmények és szakemberek közti kommunikáció támogatásában, érdekképviseletében évtizedes múlttal rendelkező szervezet. Ez garanciát jelentett arra, hogy a rajtuk keresztül továbbított meghívás az együttgondolkodásra jó fogadtatásra talál. $\mathrm{Az}$ egyesület kapcsolatrendszere egyúttal meg is határozta a bevonandó szereplők körét, ami részben limitációt jelentett, ugyanakkor érvényesíteni sikerült a multilateralitást. (2. ábra) A legfőbb limitáció az üzleti szféra kimaradása, melynek azonban jelenleg nincs jelentős szerepe a demenciával élők ellátásában sem az egészségügyi, sem a szociális területen. Érdemes lenne ugyanakkor a bevonása a jelenleg ezen a téren nem tevékenykedő magánellátóknak, mivel más területen szerzett tapasztalataik hasznosak lehetnek. A Szociális Klaszter maga az egyetlen civilként megjelenő résztvevő ebben a körben, melynek képviselői egyúttal az intézményfenntartókat (mint egyházi szervezet) és intézmény müködtetőket is képviseli, így megjelenésükben nem a civil megközelítés a hangsúlyos. A valódi civil képviseletet a kis számban már hazánkban is létező hozzátartozói támogatói fórumok (pl. Alzheimer Cafe) (Morrissey et al., 2006) részvétele jelentené.

\section{A demenciastratégia megalapozásához végzett} rendszertérképezésbe bevont szereplők

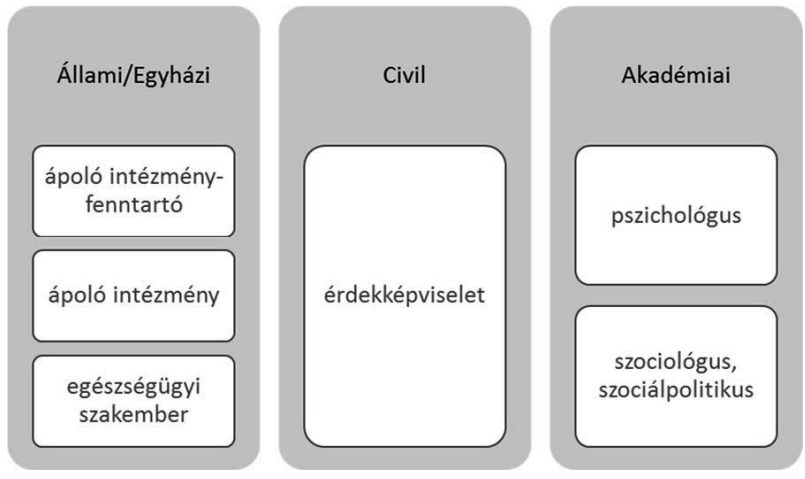

A civil szervezet vezetői tettek név szerinti javaslatot a meghívandó szereplőkre azután, hogy közösen megha- tároztuk, hogy milyen terület képviselőit hívjuk meg a beszélgetésre. Az elsődleges cél az volt, hogy gyakorlati és elméleti szakembereket egyaránt bevonjunk a gondolkodási folyamatba. Ebből viszont következik, hogy tudományos előmenetellel rendelkező szereplőktől középszintű végzettségüekig terjedhet a skála. Emiatt is volt kiemelt hangsúly az ábrakészítésen, mivel alapoztunk annak a kommunikációt megkönnyítő szerepére. A gyakorlati területet képviselő szakemberek között ápolást végző intézmény vezetőjét, egyházi intézményfenntartó vezetőt, demenciával élőket is gondozó, kezelő neurológus szakorvost, az alapellátást képviselő háziorvost, a szociális ellátás terén tapasztalattal rendelkező szociológust, míg elméleti területről a pszichológia és a szociológia területén kutató szakembereket hívtunk meg. Kiindulásként körülbelül tíz résztvevő megnyerését határoztuk meg. Minden meghívottat személyesen ismert a Szociális Klaszter felkérést kiküldő képviselője, melynek feltehetően szerepe volt abban, hogy igen jó arányú volt a meghívás elfogadása. A moderátorral együtt végül 12 fő vett részt a kísérletben.

A demenciával élők és az őket ápolók segítését célzó demenciastratégiára nem pusztán a nemzetközi elvárások miatt van szükség, hanem mivel az ellátórendszerek nagy mértékü leterhelése és a rossz hatásfokú természetbeni vagy pénzbeli állami gondoskodás, támogatás az egész társadalomra vonatkozóan jelentős hatású. A probléma komplexitása miatt különösen fontos az interdiszciplináris megközelítés, melynek során a saját koncepciók egyfajta kombinálása, hosszabb együttműködés során egymás átformálása, a társterületek szempontjainak, látásmódjának elfogadásával egy közös koncepció felállítása valósulhat meg. A stratégiaalkotás elökészítő lépésének tekinthető a szempontok összegyüjtése, mivel ez ahhoz is támpontot ad, hogy az iteratív folyamat során mely újabb és újabb szakterületek bevonása szükséges a legátfogóbb, minden tényezőre kiterjedő, konszenzuson alapuló és megvalósítható, valamint fenntartható program megalkotásához.

Ahogy azt a már kész európai nemzeti demenciastratégiáknál rendszerint láthattuk, a demencia, mint fó téma mellett egy vagy néhány kiemelt szempont köré épül fel egy-egy cselekvési terv. Prioritások meghatározása esetén a teljes program megvalósulásának lépései jobban követhetők, sikeressége jobban mérhető, ugyanakkor nem zárja ki, hogy másodlagos célokra is jusson figyelem és erőforrás. Jellemző, nem ritkán elsődlegesként vagy azok között meghatározott cél a demenciával élők diagnózishoz jutásának javítása, azaz a betegségnek a felismerése, hiszen azonosított érintettek nélkül mit sem ér egy program. Az új esetek száma, a felismert betegek között a korai stádiumban lévők arányának változása mérhető, követhető. Kiemelt célok között szerepel gyakran az ellátórendszer szükséges spektrumának felmérése és megteremtése, valamint annak müködési hatékonyságát leginkább jellemző paraméterként a demenciával élők és hozzátartozóik életminőségének javítása.

Alakuló munkacsoportunk követve ezt a mintát, úgy döntött, hogy a mind a majdani stratégiaalkotás, mind az együttgondolkodás céljából megfelelő vezérgondolat, központi cél a demenciával élők életminőségének javitása. 
A folyamat gyorsítása és a módszertan újdonsága miatt várható kezdeti nehézkesség áthidalása érdekében egy, a vezérgondolat köré épülő kezdeti fogalomtárat, a rendszertérképbe később beépíthető változó gyüjteményt állított össze a szerző a résztvevők bevonásában segédkező egyesületi munkatársak közremüködésével még a közös munka elött. Ehhez a forrást egyrészt szintén a demenciával élők, családtagjaik és ápolóik életminőségének javítását központba állító máltai demenciastratégia jelentette, másrészt a 2015 folyamán, európai uniós támogatás révén zajlott INterprofesszionális Demencia Alapprogram (INDA) adta. Az INDA programot a Római Katolikus Egyházi Szeretetszolgálat a Szociális Klaszter Egyesülettel együttműködve dolgozta ki és hajtotta végre, alapozva mindezt a Szeretetszolgálat több mint hat évtizedes, az intézményi idősellátásban szerzett fenntartói, és az Egyesület tagintézményeinek gyakorlati gondozói tapasztalatára. E két forrásból összesen 45, a demenciával élők életminőségéhez köthető változót fogalmazott meg a moderátor, melyet a résztvevők az elméleti alapozás, a módszertant röviden ismertető bevezető előadás után ismerhettek meg. A résztvevőknek a listán a megítélésük szerint legfontosabb, tetszőleges számú fogalmat kellett megjelölniük, majd a moderátor összegezte ezeket. A leggyakrabban (legalább öt résztvevő által) megjelölt tényezőket külön felírta, már az összefüggések megjelenítésére alkalmas módon (post-it), így az ábrázolás folyamata 15 változóval indult.

A találkozó helyszíne minden résztvevő számára ismert volt, több korábbi egyesületi összejövetel színtere, mely szintén fontos tényező lehet az együttgondolkodás oldottságának megvalósításához. A terveknek megfelelően először fél óra időtartamban a moderátor, jelen cikk szerzője, megismertette a módszertan alapjaival a résztvevőket. A részvételi folyamatok, a rendszerdinamikai modellezés és a vizuális nyelv alkalmazásában rejlő lehetőségeket tekintettük át röviden. Ezt követően került sor az indító fogalmak kiválasztására a fent leírt módon, és az így nyert, térképen elhelyezésre kész formában rendelkezésre álló 15 változó nagyban megkönnyítette az első, feszélyezett lépések megtételét, ugyanakkor nem volt kényszer az ily módon adott változók felhasználása.

A 2,5 órás intenzív munka eredményeként felvázolt diagram végül 42 fogalom felhasználásával készült el. (3. ábra) Ezek képezték a csomópontokat, melyeket 88 kapcsolat, úgynevezett oksági reláció kötött össze. A 88 kapcsolatból 79 pozitív, míg 9 negatív előjelü volt, és egyetlen, mindkét részről negatív előjelű kapcsolat volt kétirányú. A csomópontokhoz, változókhoz minimum egy maximum 11, átlagban 4,2 kapcsolat vezetett. Mindezeknek a statisztikáknak az elkészítését, valamint az igényes ábrázolást, az archiválást és a további elemzést megkönnyíti valamilyen szoftver alkalmazása. Jelen esetben a VUE (Visual Understanding Environment) szabad hozzáférésű szoftver segítette a munkának ezt a részét. A rendszertérképezés eredménye elsődlegesen fényképeken került rögzítésre, illetve kezelhető méretű volt az elkészített papíralapú térkép is. Mindezek felhasználásával utólag, de nem sokkal az események után került sor a szoftveren történő rögzí- tésre. A VUE szoftver is alkalmas lenne a folyamat közbeni rögzítésre, különösen, ha van egy módszertant ismerö, moderátori szerepet nem betöltő résztvevő, aki külső szemlélőként, pusztán adminisztrátorként részt tud venni az eseményen.

3. ábra

\section{A rendszertérképezés folyamatának szervezési és lebonyolítási lépései}

\section{A részvételi rendszertérképezés eredményei}

Az együttgondolkodás során elkészített térképet, a létrehozott komplex oksági diagramot már a helyszínen a résztvevőkkel közösen felületesen elemeztük. Már ekkor jól kirajzolódott, hogy a fogalmak többsége négy fö témakörhöz kötődik (4. ábra). A 42-ből 31 változó a következő szempontok egyikéhez tartozott:

- (szak)ápolói tényezők (9),

- orvosi ellátási háttér (8),

- hozzátartozói tényezők (8),

- információ - ismeret - ismertség (6).

\section{Demenciával élők életminőségét befolyásoló} 4 fö terület azonosítása

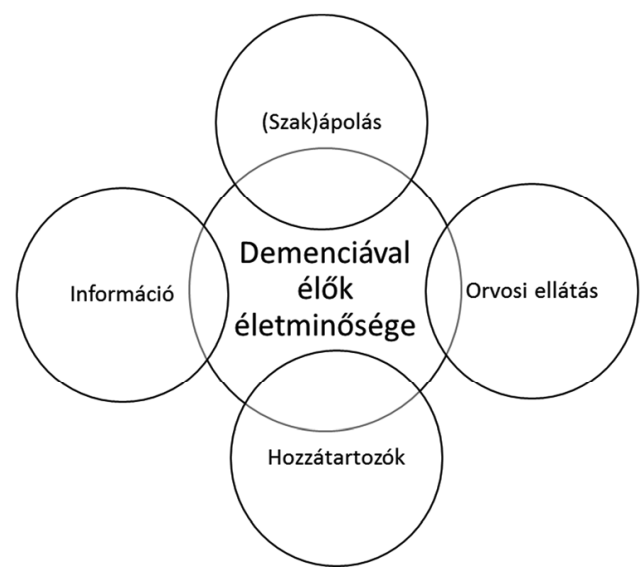

Tekintettel a résztvevők szakmai hátterének összetételére az ápolói és orvosi ellátás elötérbe kerülése talán nem meglepő. Mindenképpen magyarázható az ápolói szempont elsődlegessége azzal, hogy a demenciában jártas szakemberek tisztában vannak a ténnyel, hogy a beteg életminősége szempontjából az ápolás minősége lesz 
a legmeghatározóbb. Az össztársadalmi érintettséget leginkább kifejező fő tényező az „információ-ismeret-ismertség" gondolatkör, mely egy külön központi fogalom, a stigmatizáció köré épült. A négy fő témakörbe nem besorolható fogalmak további utalást tettek az interdiszciplináris megközelítés szükségszerüségére, mivel például finanszírozási, jogi, kutatási vonatkozásokat vetettek fel. Mindamellett tehát, hogy a kiemelt témakörök tükrözik a résztvevők kompetenciájának, jártasságának fő területeit, egyértelmüen megmutatkozik az azon túlmutató összefüggés-keresés.

Komplex oksági diagram készítésekor a pozitív és negatív irányú relációk ábrázolása teszi egyértelmúvé a kapcsolatot a változók között (Sedlacko et al., 2014). Tekintettel arra, hogy a központba helyezett változó alapvetően kimenet jellegü, így visszacsatolási hurkok könnyebben a különböző kiemelt témakörökön belül, illetve azok között létesíthetők (5. ábra).

5. ábra

Példa pozitív visszacsatolási körre

- Orvosi ellátás témakörön belül

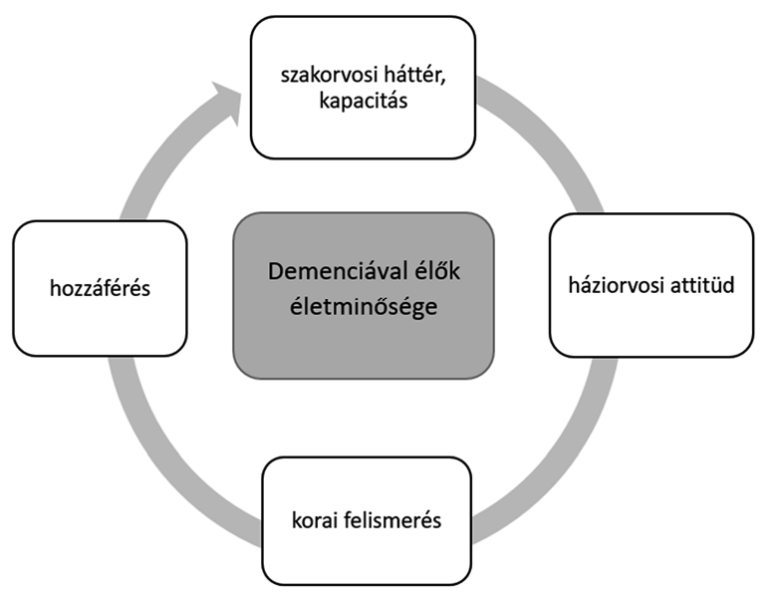

A kirajzolódott négy fó terület alapján a demenciával élők életminőségének javítása érdekében beavatkozást elsődlegesen az orvosi ellátás és az ápolás területén, a hozzátartozók támogatásában, valamint a betegséggel kapcsolatos minden típusú információ terjesztésében kell kezdeményezni. Ennek a négy témának az azonosítása akár egy stratégia megalkotásának prioritást meghatározó lépését is jelentheti (ld. 1. ábra).

\section{Következtetések}

A részvételi rendszertérképezés és a komplex oksági diagram készítése a kísérlet alapján megfelelő eszköznek tünik ahhoz, hogy segítse egy összetett társadalmi probléma kezelését célul kitűző cselekvési terv megalkotásának kezdeti lépéseinél a tudás összegzését és az elsődleges beavatkozási pontok azonosítását. A demencia mint elsődlegesen egészség- és szociálpolitikai szempontból megközelítendő, a demográfiai folyamatok alapján megbízhatóan előre jelezhető mértékű terhet jelentő probléma, ideális témája volt a kísérletnek. A többi európai országhoz képest a probléma megoldására irányuló stratégia kidolgozásában hazánk lemaradásban van, így minden, a stratégiaalkotás folyamatába illeszthető lépés gyorsíthatja a cél elérését. A részvételi rendszerdinamikai modellezés újabb és újabb területeken való alkalmazása várható a jövőben, mivel az eddigi tapasztalatok alapján alkalmas hosszú távú célok meghatározására, konkrét beavatkozási pontok azonosítására. Alkalmazása az egészségügyi és szociális területen még nemzetközi szinten is ritka. Az egészségtudományi és a közgazdasági terület egy-egy nagy, átfogó adatbázisában (Medline és EconLit) végzett keresés eredményeként mindössze 12 találatot kaptunk.

A kísérleti jelleggel végzett kutatás során a valamenynyire már meglévő konzultatív kapcsolatokra építve, a már fennálló bizalmi viszonyt kihasználva próbáltuk az újszerü megközelítés alkalmazása miatti esetleges idegenkedést és az időigényt csökkenteni. A résztvevők számos pozitív visszajelzést adtak közvetlenül a kísérlet után, majd később is a gondolataikat, véleményüket monitorozó informális találkozók során. A megfogalmazottak közül kiemelhetö, hogy többen hangsúlyozták a részvételük fontosságának megélését. Ez visszaigazolja a módszertan megfelelőségét egyrészt abban a tekintetben, hogy egyértelmúen motiváló hatású volt a részvétel biztosítása, másrészt mivel valóban kommunikációs csatornát tudott biztosítani az egyetemi kutató és az idősellátásban részt vevő, ápolási otthont irányító gyakorlati szakember között. A vizuális ábrázolással magyarázták többen, hogy a kimerítő eszmecsere végén jó érzéssel telve búcsúztak, látva a munka gyümölcsét, a szó szerint tapintható, kézzel fogható produktumot, melyet mindenki a magáénak érzett, mivel látta a saját kézírását vagy olvashatta az általa megfogalmazott gondolatot, mely az egyik csomópontja lett az ábrának.

Moderátori tapasztalat, hogy valóban körültekintően kell megválasztani a résztvevőket, mivel egy problémakör globálisnak szánt áttekintését korlátozhatja, ha valamelyik szak-/részterület képviselői túl nagy szerepet kapnak a reprezentáció mértéke vagy kommunikációs habitusuk alapján. A moderátornak akár aktív beavatkozásra, a szó átadására is készen kell állnia, ha a helyzet azt megköveteli. Bár egyszerünek tünhet az ábrázolás feladata, de a résztvevőket többször emlékeztetni kellett arra, hogy igyekezzenek a probléma komplexitására gondolva minden oksági összefüggést megtalálni és ábrázolni. Ez a képesség feltehetően a gyakorlattal vagy részletesebb elméleti előkészítéssel javítható.

A négy azonosított fö befolyásoló tényező további elemekre bontása, a részfolyamatok mélyebb feltárása is lehetséges, illetve célszerü lenne. Látva, hogy egyes területeken a komplex áttekintést kevésbé szolgáló módon túlzott részletességgel történt a változók, okok feltárása, így felmerült lehetőségként, hogy az adott területre fókuszáló gondolattérképezés is kivitelezhető lenne az adott területen járatos szereplök bevonásával. A komplexitás háttérbe szorítása ilyen esetekben a rendszertérképezés egyéb irányú hasznosítását, mint az egészségügyi és szociális területen az úgynevezett ,jó gyakorlatok” azonosítását, vagy a részvétel biztosításával a motivációt szolgálná. 
A hozzátartozók hangsúlyos szerepét a demenciával élők ellátásában jelen kutatás eredménye is megmutatta. A családtagokat a gondozói szerepben érő pozitív és negatív hatások aktívan kutatott terület, és a többségében kvantitatív módszertan mellett már kvalitatív metódusok is feltűnnek (Poland et al., 2014). A részvételnek mint módszertannak ilyen jellegű kutatásban történő alkalmazása mindenképpen megfontolandó következő lépésként, és a gondozó hozzátartozók mellett akár a demencia kezdeti stádiumában lévő érintettek bevonása sem irreális cél. A demenciával élőkkel végzett más kvalitatív módszertan alkalmazására van példa (Clare et al., 2008) a szakirodalomban, így ezek tapasztalataira lehet támaszkodni, ugyanakkor minden bizonnyal speciális felkészülésre van szükség, melynek ki kell terjednie a kórállapot tüneteinek ismeretén túl gyakorlati tapasztalat szerzésére, a demenciával élők mindennapi nehézségeinek megismerésére.

\section{Megbeszélés}

A következtetésben összefoglalt tapasztalataink alapvetően alátámasztották az irodalomkutatás alapján felállított hipotézist, mely szerint a részvételi rendszerdinamikai modellezés alkalmas eszköz lehet valamely népegészségügyi probléma részének vagy egészének feltárására, egészségpolitikai döntések meghozatalának, stratégiák megalkotásának támogatására (Leischow, 2006). A részvétel szempontjából igazolódott az a dilemma, hogy a szereplők kiválasztása egyúttal meghatározza a kimenetelt, többek között abban a tekintetben is, hogy a részvétel milyen jellegű bevonást jelent (Bishop, 2002). Esetünk leginkább ,partnerségi” típusú részvételnek volt megfeleltethető, ami alapján a meghívott szakértők akár a szakpolitika megalkotói mellett működő tanácsadó testületben is szerepet kaphatnának. A résztvevők kiválasztása szolgálta a holisztikus szemlélet és a tudásszintézis megvalósulását, melyek többek között kritikus szempontok a módszer döntéstámogató funkciójának kiaknázásában. Tapasztalataink igazolták a kutató elődök azon meglátását is, hogy a rendszerdinamika egy problémavezérelt megközelítés és a rendszertérképezésnek egy adott problémára kell fókuszálnia (Sedlacko et al., 2014).

Kutatásunkban ez a központi probléma a ,demenciával élők életminőségének javítása” volt. Célunk az erre befolyással bíró tényezők azonosítása volt. Sikeresnek mondható a kísérlet abban a tekintetben, hogy sikerült endogén, a résztvevők által képviselt területen belül visszacsatolással rendelkező tényezőket megjeleníteni, feltárni (Richardson, 2011). A demenciával élők életminőségét meghatározó és egymásra hatást gyakorló tényezők a térképünk alapján négy témakörhöz tartoztak. Ezeken a témakörökön belül számos visszacsatolás, összefüggés volt feltárható és kisebb számban a témakörök között is voltak kapcsolatok. A négy fö témakörbe nem besorolható változók, mint a finanszírozási, jogi, kutatási vonatkozások jelentették az exogén tényezőket.

Eredményeink alapján a demenciával élők életminőségét az ápolási, az orvosi ellátási, a hozzátartozói háttér, va- lamint az információ több aspektusa határozza meg, és ez egybecseng más országok kész, akár már többször megújított demenciastratégiájával, melyekben gyakran prioritásként szerepel a demenciával kapcsolatos közérthető és szakmai ismeretek terjesztése (információ), a stigmatizáció elleni küzdelem (információ), az ápoló hozzátartozók támogatása (hozzátartozói háttér), az ellátórendszer bővítése és minőségi ellátás kiépítése (ápolási és orvosi ellátási háttér).

\section{Jegyzet}

${ }^{1}$ Eurostat, 2014; http://appsso.eurostat.ec.europa.eu/nui/show.do?dataset $=$ proj_13npms\&lang $=$ en

${ }^{2}$ Doc. $96 \overline{15}, 31$ october 2002 , Challenges of social policy in our ageing societies - Report: http://assembly.coe.int/nw/xml/XRef/X2H-XrefViewHTML.asp?FileID=9911\&lang=EN

${ }^{3} \mathrm{http} / /$ www.enkk.hu/index.php/hun/kepzesi-kozpont/233-egeszseges-magyarorszag-2014-2020 (letöltve 2016.12.01.)

4 Nemzeti Szociálpolitikai Koncepció 2011-2020; 2011, Czibere Károly, Sziklai István, Mester Dániel, Dr. Vörös Gyula, Sidlovics Ferenc, Skultéti József, Beszterczey András

${ }^{5}$ Köszönetnyilvánítás: A szerző ezúton fejezi ki köszönetét az egyesület vezetőjének, Dr. Egervári Ágnesnek, és munkatársának, Dr. Vajda Norbertnek a kutatás megvalósításához nyújtott segítségükért, támogató és ösztönző javaslataikért, valamint minden résztvevőnek az együttmüködésért.

${ }^{6} \mathrm{http}$ //alzheimer-europe.org/Alzheimer-Europe/Who-we-are/ Our-members (letöltve: 2016.12.12.)

${ }^{7}$ A moderátori feladatkört a cikk szerzője, a kísérlet kiötlője látta el. A szerző orvosszakértői tevékenysége során találkozik demenciával élö, aktív korú betegekkel és ápoló hozzátartozóikkal, gondozóikkal, valamint tagként segíti a Szociális Klaszter Egyesület munkáját.

${ }^{8} \mathrm{http}$ ://inda.info.hu/

9 1. demencia ismertsége, 2. korai felismerés, 3. információmennyiség a neten, 4. pozitív háziorvosi attitüd, 5. szakorvosi háttér és kapacitás, 6. Alzheimer Cafe, 7. család jövedelme, 8. prevenció, 9. demenciával élők életminősége, 10. palliatív szemlélet, 11. ellátáshoz való hozzáférés, 12. stigma, 13. kutatás, 14. adatgyüjtés, 15. életvégi döntések lehetösége, 16. demenciabarát kommunikáció, 17. informáló kiadványok, 18. önkéntes segítés, 19. long-term-care, palliatív kapacitás, 20. kapacitásigény ismerete, 21 . betegségspecifikus finanszírozás, 22. rugalmas ellátás megvalósulása, 23. ellátásban résztvevők kapcsolatai, 24. illeszkedő jogi háttér, 25. hozzátartozói támogatás eredményessége, 26. hozzátartozó életminősége, 27. beteg jövedelme, 28. rugalmas ellátási formák, 29. ápolói presztízs, 30. otthoni ellátás feltétele, 31. hozzátartozó motiváltsága, 32. lakhatási körülmény, 33. ápolói burn-out, 34. munkakörülmény, 35. ápoló életminősége, 36. ápolói létszám, 37. ápolók speciális képzése, 38. rugalmas munkalehetőség, 39. TB-juttatások köre, 40. betegségspecifikus pénzbeli ellátás, 41. gondozási igény felmérése, 42. rugalmas ellátás kapacitása.

${ }^{10} \mathrm{http}: / /$ vue.tufts.edu/

${ }^{11}$ keresési metódus: via EBSCOhost: ( "systems thinking" OR "system dynamics approach" OR "causal loop diagram" ) AND ( policy OR strategy ) AND ( health OR social ) AND ( participation OR participatory )

${ }^{12} \mathrm{http}$ ://alzheimer-europe.org/Policy-in-Practice2/National-Dementia-Strategies (letölve: 2017.02.27.)

\section{Felhasznált irodalom}

Aguero-Torres et al. (1998): Dementia is the major cause of functional dependence in the elderly. Three-year follow-up data from a population-based study. American Journal of Public Health, 88(10), p. 1452-1456.

Annear, M. J. et al. (2015): What should we know about dementia in the 21st Century ? A Delphi consensus study. BMC Geriatrics, 15 (5), p. 1-13.

Bishop, P. - Davis, G. (2002): Mapping public participation in policy choices. Australian Journal of Public Administration, 61(1), p. 14-29.

Christensen, K. - Doblhammer, G. - Rau, R. - Vaupel, J. $W$. (2009): Ageing populations: the challenges ahead. Lancet, 374(9696), p. 1196-1208. 
Clare, L. - Rowlands, J. - Bruce, E. -Surr, C. - Downs, M. (2008): 'I don't do like I used to do': A grounded theory approach to conceptualising awareness in people with moderate to severe dementia living in long-term care. Social Science and Medicine, 66(11), p. 2366-2377.

Etters, L. - Goodall, D. - Harrison, B. E. (2008): Caregiver burden among dementia patient caregivers: A review of the literature. Journal of the American Academy of Nurse Practitioners, 20(8), p. 423-428.

EUROCODE Project: Dementia in Europe Yearbook 2006, Alzheimer Europe; elérhető: http://ec.europa. eu/health/major_chronic_diseases/diseases/dementia/ index_en.htm\#fragment 3

Fonareva, I. - Oken, B. S. (2014): Physiological and functional consequences of caregiving for relatives with dementia. International Psychogeriatrics, 26(5), p. 725-747.

Király, G. - Köves, A. - Pataki, Gy. - Kiss, G. (2016): Assessing the Participatory Potential of Systems Mapping. Systems Research and Behavioral Science, 33(4), p. 496-514.

Király G. - Köves A. - Pataki Gy. - Kiss G. (2014): Rendszermodellezés és részvétel: egy magyar kísérlet tanulságai. Szociológiai Szemle, 24(2), p. 90-115.

Kling, M. A. et al. (2013): Vascular Disease and Dementias: Paradigm Shifts to Drive Research in New Directions. Alzheimers Dement, 9(1), p. 76-92.

Kovács Tibor (2016): Demencia a mindennapi gyakorlatban - Összefoglaló közlemény. Korszerü Kaleidoszkóp, 2. évf. 2. szám, p. 3-8.

Krol, M. - Papenburg, J. - van Exel, J. (2014): Does Including Informal Care in Economic Evaluations Matter? A Systematic Review of Inclusion and Impact of Informal Care in Cost-Effectiveness Studies. PharmacoEconomics, 33(2), p. 123-135.
Lane, D. C. (2007): The power of the bond between cause and effect: Jay Wright Forrester and the field of system dynamics. System Dynamics Review, 23(2-3), p. 95-118.

Leischow, S. - Milstein, B. (2006): Systems Thinking and Modeling for Public Health Practice. American Journal of Public Health, 96(3), p. 403-405.

Morrissey et al. (2006): Alzheimer's cafe for people with and affected by dementia, Nursing Times, 102(15), p. 29-31.

Poland, F. - Mapes, S. - Pinnock, H. - Katona, C. - Sorensen, S. - Fox, C. - Maidment, I. D. (2014): Perspectives of carers on medication management in dementia: lessons from collaboratively developing a research proposal. BioMed Central Research Notes, 7, p. 463.

Priority Medicines for Europe and the World - A Public Health Approach to Innovation. (2013): World Health Organization

Richardson, G. P. (2011): Reflections on the Foundations of System Dynamics. System Dynamics Review, 27(3), p. 219-243.

Sedlacko, M. - Martinuzzi, A. - Røpke, I. - Videira, N.Antunes, P. (2014): Participatory systems mapping for sustainable consumption: Discussion of a method promoting systemic insights. Ecological Economics, 106, p. 33-43.

Vennix, J. A. M. (1996): System dynamics: problem identification and system conceptualization. In: Vennix, J. A. M. (1996): Group Model Building - Facilitating Team Learning Using System Dynamics. Chichester: John Wiley \& Sons, p. 43-68.

World Alzheimer Report (2010): The Global Economic Impact of Dementia. Alzheimer's Disease International

World Alzheimer Report (2015): The Global Impact of Dementia. Alzheimer's Disease International 